\title{
BIOKONVERSI BAHAN BERLIGNOSELULOSA MENJADI BIOETANOL MENGGUNAKAN Aspergillus niger DAN Saccharomyces cereviciae
}

\author{
Bioconversion of Lignocellulosis Materials to Bioethanol Using Aspergillus niger and Saccharomyces \\ cereviciae
}

\author{
Muhammad Daud ${ }^{1 \boxplus}$, Wasrin Safii' ${ }^{2}$ dan Khaswar Syamsu³ \\ ${ }^{1}$ Alumni Sekolah Pascasarjana IPB, Kampus Darmaga, Bogor \\ ${ }^{2}$ Departemen Hasil Hutan Fakultas Kehutanan, Institut Pertanian Bogor, Kampus Darmaga, Bogor \\ ${ }^{3}$ Departemen Teknologi Industri Pertanian, Institut Pertanian Bogor, Kampus Darmaga, Bogor
}

\begin{abstract}
This study aims to determine the feseability of bioethanol production from lignocellulosic material by using simulataneous saccharification and fermentation (SSF) processes with Aspergillus niger dan Saccharomyces cereviciae. Three different lignocellulosic materials namely sengon wood (Paraserianthes falcataria), gmelina wood (Gmelina arborea), pinus wood and (Pinus merkusii) were pretreated using kraft process to remove lignin content. Then, pulp was treated by using SSF processes. SSF runs were performed in $500 \mathrm{ml}$ fermentors using a total slurry $200 \mathrm{ml}$. The substrate and nutrient media were autoclaved $\left(121{ }^{\circ} \mathrm{C}\right.$ and 20 minutes). The samples diluted to $2.5 \%\left(\mathrm{w} \mathrm{v} \mathrm{v}^{-1}\right)$ of total slurry was used as substrate. The substrate was added with $10 \%\left(\mathrm{v} \mathrm{v}^{-1}\right)$ A. niger $\left(6.5 \times 107 \mathrm{CFU} \mathrm{CC}^{-1}\right)$ of total slurry and then inoculated with $10 \%\left(\mathrm{~V} \mathrm{v}^{-1}\right)$ yeast $S$. cereviciae $\left(1.5 \times 109 \mathrm{CFU} \mathrm{Cc}^{-1}\right)$. The SSF experiments were run for 96 hours and the data were investigated periodically every 24 hours. The results showed that total of sugar and reducing sugar tended to decrease with time of inoculation whereas ethanol concentration increase significantly. The growth of $A$. niger and yeast $S$. cereviciae tended to incease in initial inoculation and decrease by the end of inoculation. The bioethanol concentration on sengon, gmelina, and pinus were $0.53,0.45$ and $0.31 \%$ respectively and produced yields $3.61,4.60$ and $4.16 \%$ respectively.
\end{abstract}

Key words: bioethanol, simultaneous saccharification and fermentation, Aspergillus niger, Saccharomyces cereviciae

\section{PENDAHULUAN}

Kebutuhan energi dunia akan terus meningkat sejalan dengan pertambahan penduduk dan pertumbuhan ekonomi. Peningkatan kebutuhan bahan energi terutama bahan bakar fosil tersebut telah menyebabkan penurunan cadangan minyak dunia sehingga bahan bakar fosil ini menjadi semakin langka dan harganya pun meningkat secara signifikan. Di sisi lain, perkembangan industri berbahan bakar fosil telah menyebabkan dampak lingkungan dan pemanasan global. Salah satu cara mengurangi krisis energi dan dampak yang diakibatkan oleh penggunaan energi berbahan baku

Diterima: 30 September 2011; Disetujui: 28 Desember 2011

$\triangle$ Penulis korespondensi (corresponding author): daud_forest@yahoo.com fosil adalah pengembangan energi alternatif baru dan terbarukan seperti bahan bakar nabati (BBN). Selain dapat diperbaharui, BBN ini juga dapat mengurangi emisi akibat pembuangan gas-gas rumah kaca sehingga dapat mengurangi dampak pemanasan global (Smith et al., 2003; Samejima, 2008).

BBN merupakan salah satu sumber energi yang mudah diperoleh di Indonesia. Banyak jenis sumber energi alternatif yang dapat diolah menjadi BBN seperti jarak pagar, kelapa sawit (biodiesel), tebu, ubi kayu dan aren (bioetanol). Selama ini, produksi bioetanol diarahkan pada bahan berpati dan bergula seperti gula tebu, ubi kayu dan jagung. Padahal bahan-bahan tersebut pada dasarnya merupakan sumber pangan yang cukup potensial, sehingga pengembangan bioetanol dari bahan pangan tersebut ke depan akan dapat menimbulkan 
permasalahan baru akibat persaingan terhadap pemenuhan kebutuhan pangan masyarakat. Oleh karena itu, perlu pengembangan bioetanol dari bahan yang bukan merupakan sumber pangan masyarakat yaitu terutama bahan berlignoselulosa sehingga memungkinkan ke depan untuk pemanfaatan limbah-limbah kayu di hutan dan limbah industri untuk bioenergi serta pengembangan hutan tanaman industri untuk energi di Indonesia.

Beberapa bahan berlignoselulosa yang memiliki potensi yang sangat besar untuk dijadikan bahan baku produksi bioetanol di Indonesia adalah tumbuhan berkayu. Pemanfaatan bahan berlignoselulosa sebagai penghasil bioetanol telah mulai diteliti dan dikembangkan (Ingram, 1997; Boussaid et al., 1999; Spagnuolo et al., 1999; Smith et al., 2003; Samejima, 2008). Bahan berlignoselulosa yang telah diteliti sebagai penghasil bioetanol adalah bagas (Martinez et al., 2000), jerami (Neureiter et al., 2002) dan kayu (Ingram et al., 1997; Spagnuolo et al., 1999; Boussaid et al., 1999; Stenberg et al., 1998; Stenberg et al., 1999; Stenberg et al., 2000).

Harga bahan baku berlignoselulosa pada dasarnya secara ekonomis lebih murah dan lebih mudah diperoleh serta dapat dikembangkan pada lahan yang tidak dapat dikembangkan untuk kepentingan pertanian namun pengembangan bahan berlignoselulosa ini masih menemui kendala seperti rendemen bioetanol yang masih rendah dan memerlukan biaya produksi yang tinggi yang terutama diakibatkan oleh rendahnya kerja enzim pada substrat akibat sifat kristalinitas selulosa dan kehadiran zat penghambat (inhibitors) yang dapat mengurangi fermentabilitas selulosa dan hemiselulosa menjadi etanol (Stenberg et al., 1998; Stenberg et al., 1999). Oleh karena itu, untuk memproduksi bioetanol dari kayu maka diperlukan optimalisasi teknologi proses produksi terutama pada proses perlakuan pendahuluan (pretreatment), hidrolisis (sakarifikasi) dan fermentasi. Salah satu metode yang dapat meningkatkan produktivitas bioetanol adalah dengan menggunakan metode sakarifikasi dan fermentasi secara simultan atau simultaneous saccharification and fermentation (SSF). Penelitian ini bertujuan untuk menganalisis pemanfaatan kultur murni $A$. niger dan S. cereviciae dalam produksi bioetanol dari berbagai bahan baku lignoselulosa dengan menggunakan metode SSF.

\section{BAHAN DAN METODE}

\section{Bahan dan Alat}

Alat yang digunakan dalam penelitian ini adalah parang, hammer mill, saringan 40 dan 60 mesh, penangas air, stirrer, gelas piala $400 \mathrm{ml}$, Erlenmeyer $250 \mathrm{ml}$, filter, pengaduk kaca, glass filter, timbangan, oven, gelas piala $200 \mathrm{ml}$, thermometer, thimble ekstraksi, sohklet, kondensor, corong buchner, glass filter, filtering flask, Erlenmeyer $1.000 \mathrm{ml}$, gelas piala $100 \mathrm{ml}$, gelas piala $50 \mathrm{ml}$, pipet volume, Erlenmeyer $300 \mathrm{ml}$, tank stainless steel, digester, mixer, lampu spirtus, ruang laminar, inkubator, bulb, sprayer, autoklaf, sentrifuse, $\mathrm{pH}$ meter, toples, gelas kimia, labu ukur, pengaduk, labu semprot, pipet skala, pipet mikron, labu isap, corong, alat fermentasi, ose, tabung reaksi, sprayer, buret, hot plate, timbangan digital, botol Schott, alat fermentasi, $X$ ray difraction merk Shimadzu, Spektrofotometer dan Gas Chromatography (GC).

Bahan yang digunakan dalam penelitian ini adalah serbuk dari beberapa kayu tropis yaitu dua jenis kayu daun lebar yaitu kayu sengon ( $P$. falcataria (L) Nielsen.) dan gmelina (G. arborea Roxb.), satu jenis kayu daun jarum yaitu pinus ( $P$. merkusii Jung. et de $\mathrm{Vr}$.), bahan-bahan kimia seperti $\mathrm{NaOH}, \mathrm{Na}_{2} \mathrm{~S}$, asam asetat $\left(\mathrm{CH}_{3} \mathrm{COOH}\right) 10 \%$, etanol $\left(\mathrm{C}_{2} \mathrm{C}_{5} \mathrm{OH}\right)$, benzena $\left(\mathrm{C}_{6} \mathrm{H}_{6}\right)$, asam sulfat $\left(\mathrm{H}_{2} \mathrm{SO}_{4}\right)$, natrium klorit $\left(\mathrm{NaClO}_{2}\right.$, asam asetat glasial, asam nintrat $\left(\mathrm{HNO}_{3}\right)$ $3,5 \%, \mathrm{Na}_{2} \mathrm{SO}_{3}$. Isolat yang digunakan adalah kapang A. nigerdan khamir S. cereviceae. Bahan lain adalah aluminium foil, air suling, glukosa, kertas saring, kertas tisu, kapas, dan kertas label, kertas saring, kertas label, tabung eppendorf, botol sampel $30 \mathrm{ml}$, potatoe dextrose agar (PDA), alkohol $96 \%$, ekstrak khamir, malt, pepton, glukosa, 3,5-dinitrosalisilat, aliumnatriumtartrat-tetrahydrat $\left(\mathrm{C}_{4} \mathrm{H}_{4} \mathrm{KNaO}_{6} \cdot 4 \mathrm{H}_{2} \mathrm{O}\right)$, phenol, $\mathrm{Na}$-Metabisulfit, $\mathrm{HCl}$, indikator fenolptalein, buffer sitrat $\mathrm{pH} 5$, nutrisi media yang terdiri atas $\left(\mathrm{NH}_{4}\right)_{2} \mathrm{HPO}_{4}$ dan $\mathrm{MgSO}_{4} \cdot 7 \mathrm{H}_{2} \mathrm{O}$.

\section{Metode}

\section{Perlakuan Pendahuluan dengan Menggunakan Proses Kraft}

Sampel uji ekuivalen $200 \mathrm{~g}$ bobot kering ditempatkan dalam digester. Larutan pemasak $\mathrm{NaOH}$ dan $\mathrm{Na}_{2} \mathrm{~S}$ disiapkan sesuai dengan kebutuhan. Banyaknya kebutuhan larutan pemasak dihitung berdasarkan kondisi pemasakan yang 
digunakan sebagai berikut: alkali aktif $\left(\mathrm{Na}_{2} \mathrm{O}\right)$ dan sulfiditas untuk masing-masing kayu bervariasi tergantung dari penelitian proses perlakuan pendahuluan terbaik pada penelitian sebelumnya yaitu alkalinitas $18 \%$ dan sulfiditas $25 \%$ pada kayu pinus dan sengon, alkalinitas $20 \%$ dan sulfiditas 25 $\%$ pada kayu gmelina, rasio serpih dengan larutan pemasak $1: 4$, sulfiditas 20 dan $25 \%$. Suhu maksimum pemasakan sekitar $170{ }^{\circ} \mathrm{C}$ dengan lama pemasakan 4 jam. Setelah itu, akan diperoleh pulp hasil delignifikasi kayu. Pulp kemudian dihitung rendemen dan bilangan kappanya.

\section{SSF dengan Isolat Jamur A. niger}

SSF dilakukan dalam satu fermentor (Erlenmeyer). Berat substrat yang digunakan adalah $5 \mathrm{~g}$ untuk masing-masing substrat. Pulp yang diperoleh dari perlakuan pendahuluan dan fraksinasi kemudian diencerkan sampai mencapai

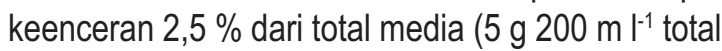
media). Media SSF diberi dengan nutrien dengan konsentrasi masing-masing $0,5 \mathrm{~g} \mathrm{l}^{-1}\left(\mathrm{NH}_{4}\right)_{2} \mathrm{HPO}_{4}$; $0.025 \mathrm{~g} \mathrm{l}^{-1} \mathrm{MgSO}_{4} .7 \mathrm{H}_{2} \mathrm{O}$. pH awal yang digunakan adalah sekitar 4,9-5,0 diatur dengan menggunakan $\mathrm{NaOH}$ dan $\mathrm{HCl}$, kemudian dipertahankan dengan buffer sitrat $\mathrm{pH} 5$. Substrat dan media nutrient dimasukkan ke dalam autoklaf pada suhu $121^{\circ} \mathrm{C}$ selama 20 menit. Setelah itu ditambahkan isolat jamur A.niger (6,5 x $\left.107 \mathrm{CFU} \mathrm{CC}^{-1}\right)$ dan ekstrak jamur S.cereviciae $\left(1,5 \times 109 \mathrm{CFU} \mathrm{CC}^{-1}\right)$ masing-masing sebanyak $10 \%$. Proses SSF dilakukan selama 96 jam pada suhu konstan $30^{\circ} \mathrm{C}$. Pengamatan dilakukan setiap 24 jam. Pada akhir fermentasi dihitung kadar etanol, gula pereduksi, total gula dan jumlah A. niger dan khamir S. cereviciae.

\section{Metode Analisis Selama Kultivasi}

\section{Penentuan Total Gula dengan Metode Fenol $\mathrm{H}_{2} \mathrm{SO}_{4}$}

Penentuan total gula didasarkan pada metode Dubois et al. (1956). Sebelum melakukan pengujian sampel maka perlu diketahui kurva standar fenol yang digunakan. Kurva standar fenol adalah sebagai berikut: $2 \mathrm{ml}$ larutan glukosa standar yang mengandung $0,10,20,30,40,50$ dan $60 \mathrm{mg} \mathrm{l}^{-1}$ glukosa masing-masing dimasukkan ke dalam tabung reaksi, ditambahkan $1 \mathrm{ml}$ larutan fenol $5 \%$ dan dikocok. Kemudian $5 \mathrm{ml}$ asam sulfat $\left(\mathrm{H}_{2} \mathrm{SO}_{4}\right)$ pekat ditambahkan dengan cepat. Biarkan selama 10 menit, kemudian dikocok lalu tempatkan dalam penangas air selama 15 menit. Absorbannya diukur pada $490 \mathrm{~nm}$ dengan menggunakan spektrofotometer. Pengujian sampel sama dengan pembuatan kurva standar fenol, hanya $2 \mathrm{ml}$ larutan glukosa diganti dengan $2 \mathrm{ml}$ sampel.

\section{Penentuan Gula Pereduksi dengan Metode DNS}

Penentuan gula pereduksi dilakukan berdasarkan metode Miller (1959). Prinsip metode ini adalah dalam suasana alkali gula pereduksi akan mereduksi asam 3,5-dinitrosalisilat (DNS) membentuk senyawa yang akan diukur absorbannya pada panjang gelombang $550 \mathrm{~nm}$.

Pereaksi DNS dibuat dengan melarutkan 10,6 g asam 3,5-dinitrosalisilat dan $19,8 \mathrm{NaOH}$ ke dalam $1.416 \mathrm{ml}$ air. Setelah itu, ditambahkan $306 \mathrm{~g} \mathrm{Na}-$ K-Tatrat, $7,6 \mathrm{~g}$ fenol yang dicairkan pada suhu 50 ${ }^{\circ} \mathrm{C}$ dan 8,3 g Na-Metabisulfit. Larutan ini diaduk rata, kemudian $3 \mathrm{ml}$ larutan ini dititrasi dengan $\mathrm{HCl} \mathrm{N}$ dengan indikator fenolftalein. Banyaknya titran berkisar 5 sampai dengan 6 . Jika kurang dari itu harus ditambahkan $2 \mathrm{~g} \mathrm{NaOH}$ untuk setiap $\mathrm{ml}$ kekurangan $\mathrm{HCl} 0,1 \mathrm{~N}$.

Kurva standar dibuat dengan mengukur nilai gula pereduksi pada glukosa $0 ; 0,1 ; 0,2 ; 0,3 ; 0,4$; 0,5 ; dan $0,6 \mathrm{~g} \mathrm{I}^{-1}$. Nilai gula pereduksi diukur dengan metode DNS. Hasil yang didapatkan diplotkan dalam grafik secara linear.

Pengujian gula pereduksi menggunakan kurva standar DNS adalah sebagai berikut: sebanyak 1 $\mathrm{mL}$ sampel dimasukkan ke dalam tabung reaksi, kemudian ditambahkan $3 \mathrm{ml}$ pereaksi DNS larutan tersebut ditempatkan dalam air mendidih selama 5 menit. Biarkan sampai dingin pada suhu ruang. Ukur absorbansnya pada panjang gelombang $550 \mathrm{~nm}$.

\section{Pengujian Kadar dan Rendemen Etanol}

Pengujian kadar etanol dilakukan dengan menggunakan GC (Gas Chromatography). Sebelum pengukuran dibuatkan dulu kurva standar dengan menggunakan etanol murni. Rendemen dihitung dengan membandingkan volume etanol yang diperoleh dengan berat sampel bahan baku yang digunakan. Pemilihan proses produksi terbaik didasarkan pada rendemen etanol tertinggi. Rumus yang digunakan untuk menghitung rendemen etanol $\left(\% \vee v^{-1}\right)$ adalah sebagai berikut:

$R=$ Volume etanol yang diperoleh secara aktual $(\mathrm{ml}) \times 100 \%$ Volume Bahan Baku (ml) 


\section{Perhitungan Jumlah Mikroba}

Jumlah mikroba dihitung dengan pengamatan di bawah mikroskop dengan metode hitungan mikroskop (haemacytometer) pada perhitungan jamur S. cereviciae dan metode total plate count (TPC) pada perhitungan jamur $A$. niger.

\section{HASIL DAN PEMBAHASAN}

\section{Komponen Kimia Pulp}

Hasil analisis pulp hasil delignifikasi dengan metode kraft ditunjukkan pada Tabel 1. Tidak ada perbedaan kadar holoselulosa dan selulosa yang signifikan di antara bahan baku. Perbedaan nyata sifat kimia bahan baku umumnya terlihat pada kadar hemiselulosa dan lignin. Kadar hemiselulosa tertinggi pada kelapa sawit $(11,70 \%)$ dan terendah pada gmelina $(8,96 \%)$. Kadar lignin tertinggi pada kayu pinus $(3,21 \%)$ dan terendah pada kelapa sawit $(1,70 \%)$.

Kadar holoselulosa pulp yang tinggi dan kadar lignin yang rendah diharapkan mampu meningkatkan rendemen etanol yang dihasilkan. Tujuan utama perlakuan pendahuluan adalah menghilangkan lignin, mengurangi degradasi holoselulosa selama perlakuan pendahuluan sehingga menghasilkan total karbohidrat (holoselusa) yang tinggi, mereduksi sifat kristalinitas selulosa dan meningkatkan permukaan kontak enzim sehingga dapat memudahkan proses sakarifikasi holoselulosa sehingga diperoleh rendemen gula yang tinggi yang selanjutnya difermentasi menjadi etanol.

\section{Rendemen dan Bilangan Kappa}

Proses pulping adalah proses yang bertujuan untuk mendegradasi lignin untuk menghasilkan pulp yang mengandung holoselulosa sebanyak- banyaknya. Banyaknya komponen kayu yang tidak terdegradasi setelah proses pulping ini dinyatakan sebagai rendemen. Perbedaan rendemen yang dihasilkan pada berbagai jenis bahan baku ini disebabkan oleh perbedaan komponen kimianya terutama holoselulosa dan lignin serta reaksi yang terjadi selama proses pulping. Semakin tinggi kandungan holoselulosa bahan baku yang tidak terdegradasi selama proses pulping menyebabkan rendemen bahan baku juga meningkat.

Rendemen dan bilangan kappa pulp hasil delignifikasi ditunjukkan pada Tabel 2. Rendemen tertinggi terdapat pada kayu pinus dan gmelina. Rendemen yang tinggi diharapkan mampu menghasilkan gula tertinggi pada saat konversi selulosa dan hemiselulosa menjadi glukosa.

Bilangan kappa merupakan indikatorkandungan lignin sisa di dalam pulp. Bilangan kappa yang tinggi menunjukkan kandungan lignin sisa pulp masih tinggi, tingkat kematangan dan delignifikasinya rendah sehingga menghasilkan pulp dengan kualitas yang kurang baik.

Data bilangan kappa untuk masing-masing perlakuan ditunjukkan pada Tabel 2. Hasil analisis ragam menunjukkan bahwa jenis bahan baku berpengaruh nyata terhadap bilangan kappa sedangkan alkalinitas dan sulfiditas berpengaruh tidak nyata. Hal ini mengindikasikan bahwa kombinasialkalinitas dan sulfiditas tidakberpengaruh secara signifikan terhadap bilangan kappa tetapi lebih ditentukan jenis bahan baku yang digunakan.

Berdasarkan Tabel 2, bilangan kappa tertinggi berturut-turut pada pinus, kemudian sengon dan gmelina. Tingginya lignin sisa pada kayu pinus disebabkan jenis ini termasuk kayu daun jarum yang didominasi oleh jenis lignin guaiasil yang sulit terhidrolisis. Walaupun kayu gmelina dan sengon, keduanya termasuk kayu daun lebar

Tabel 1. Sifat kimia pulp hasil delignifikasi

\begin{tabular}{cccc}
\hline Jenis Bahan Baku & Selulosa (\%) & Hemiselulosa (\%) & Lignin (\%) \\
\hline Pinus & 85,74 & 10,84 & 3,21 \\
Sengon & 85,00 & 11,18 & 2,23 \\
Gmelina & 85,96 & 8,96 & 2,07 \\
\hline
\end{tabular}

Tabel 2. Rendemen dan bilangan kappa pulp hasil delignifikasi

\begin{tabular}{ccc}
\hline Jenis Bahan Baku & Rendemen (\%) & Bilangan Kappa \\
\hline Pinus & 61,04 & 21,54 \\
Sengon & 51,65 & 15,23 \\
Gmelina & 60,84 & 11,24 \\
\hline
\end{tabular}




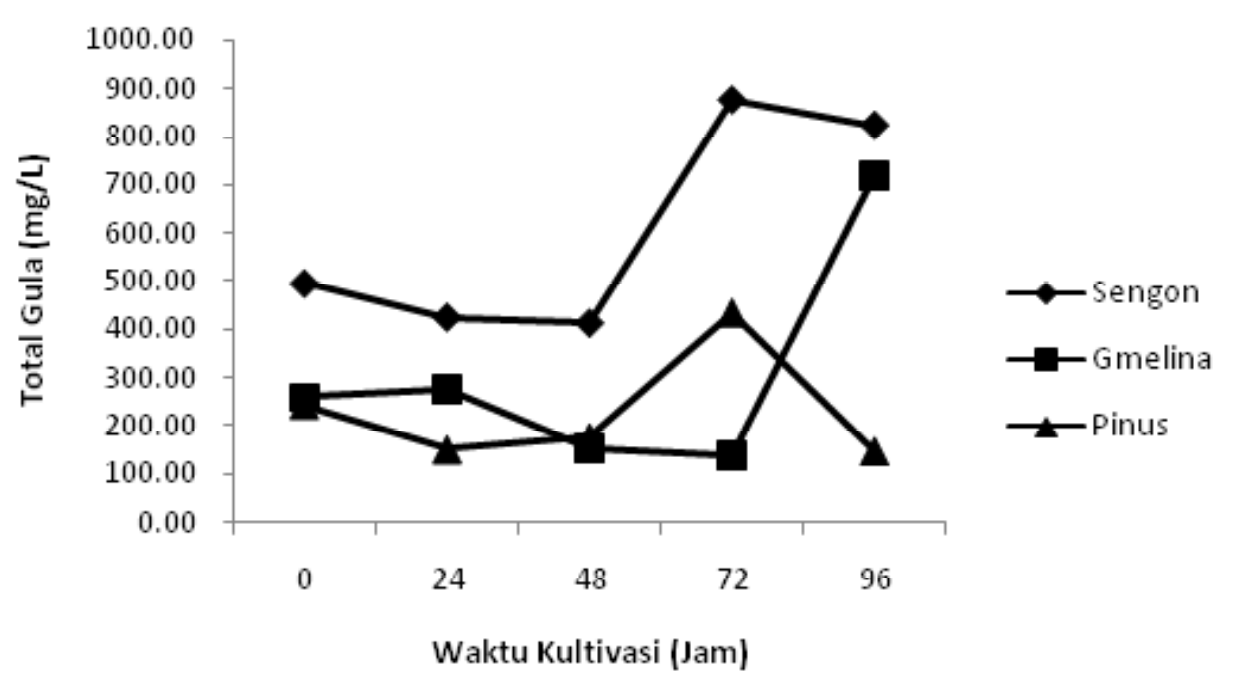

Gambar 1. Total Gula pada SSF dengan A. niger

namun diduga S/G rasio pada kayu sengon lebih rendah (ligninnya didominasi guaiasil) dibandingkan dengan gmelina. Menurut Syafii (2001) dan Syafii et al. (2009), perbedaan komposisi siringil dan guaiasil pada lignin kayu daun lebar dapat menyebabkan perbedaan laju delignifikasi. Semakin tinggi kandungan siringil dibandingkan guaiasil dalam kayu akan menyebabkan kandungan metoksil yang semakin tinggi pula, sehingga lignin bersifat lebih reaktif dan berimplikasi pada semakin cepatnya laju delignifikasi dan semakin mudahnya proses pulping berlangsung. Hasil penelitian Syafii (2001) menunjukkan bahwa lignin kayu sengon memiliki $\mathrm{S} / \mathrm{G}$ rasio sebesar 2,03.

Sisa lignin yang terdapat dalam pulp disebabkan oleh adanya ikatan antara lignin dan karbohidrat yang dikenal dengan lignin-carbohydrate complexes (LCCs) yang tidak dapat dihidrolisis oleh alkali aktif. Lignin umumnya tidak pernah ditemukan dalam bentuksederhana diantara polisakarida-polisakarida dinding sel, tetapi selalu bergabung atau berikatan dengan polisakarida tersebut. Bentuk ikatan LCCs beranekaragam pada setiap jenis tanaman. Ikatan lignin dengan karbohidrat ini terjadi melalui ikatan kovalen (Jeffries, 1994).

Ikatan antara lignin dan karbohidrat yang bersifat stabil lebih banyak ditemukan pada ikatan LCCs adalah ikatan ester. Ikatan ester terjadi antara gugus karboksil bebas dari asam uronik pada hemiselulosa dan gugus benzil pada lignin (Jeffries, 1994). Jenis ikatan lain yang ditemukan pada ikatan LCCs adalah ikatan eter dan glikosida.

\section{Total Gula}

Gambar 1 menunjukkan perubahan total gula yang dihasilkan selama proses kultivasi. Penggunaan kultur $A$. niger menghasilkan total gula awal pada kayu pinus, gmelina, dan sengon berturutturut sebesar 243,57; 260,89; dan $494.46 \mathrm{mg} \mathrm{l}^{-1}$. Rendahnya produksi total gula ini disebabkan enzim selulase yang dihasilkan oleh $A$. niger masih sedikit sehingga jumlah selulosa dan hemiselulosa yang dikonversi menjadi gula-gula sederhana juga masih rendah. Menurut Selvakumar et al. (1996), A. niger merupakan kapang yang dikenal sebagai penghasil asam sitrat, anilin, pektinase, selulase, $\beta-1,4$ glikan hidrolase, protease, $\alpha$-amilase, glukoamilase, maltase, $\quad \beta$-galaktosidase, $\alpha$-glukosidase, $\beta$-glukosidase, asam glukonat, glukosa oksidase, asam oksalat, fosfodiestrase, ribonuklease, pupulan 4-glukanohidrolase, $\beta$-xilosidase, xilanase dan lipase. Keberdaan enzim selulase inilah yang menyebabkan kapang ini mampu menghidrolisis selulosa dan sebagian hemiselulosa menjadi gula pereduksi seperti glukosa.

\section{Gula Pereduksi dan Kadar Etanol}

Sebagian besar karbohidrat, terutama golongan monosakarida dan disakarida seperti glukosa, fruktosa, galaktosa, dan laktosa mempunyai sifat mereduksi. Sifat mereduksi dari karbohidrat disebabkan oleh adanya gugus aldehida atau gugus keton bebas.

Dalam hidrolisis selulosa secara enzimatis, selulase mendegradasi selulosa menghasilkan gula 


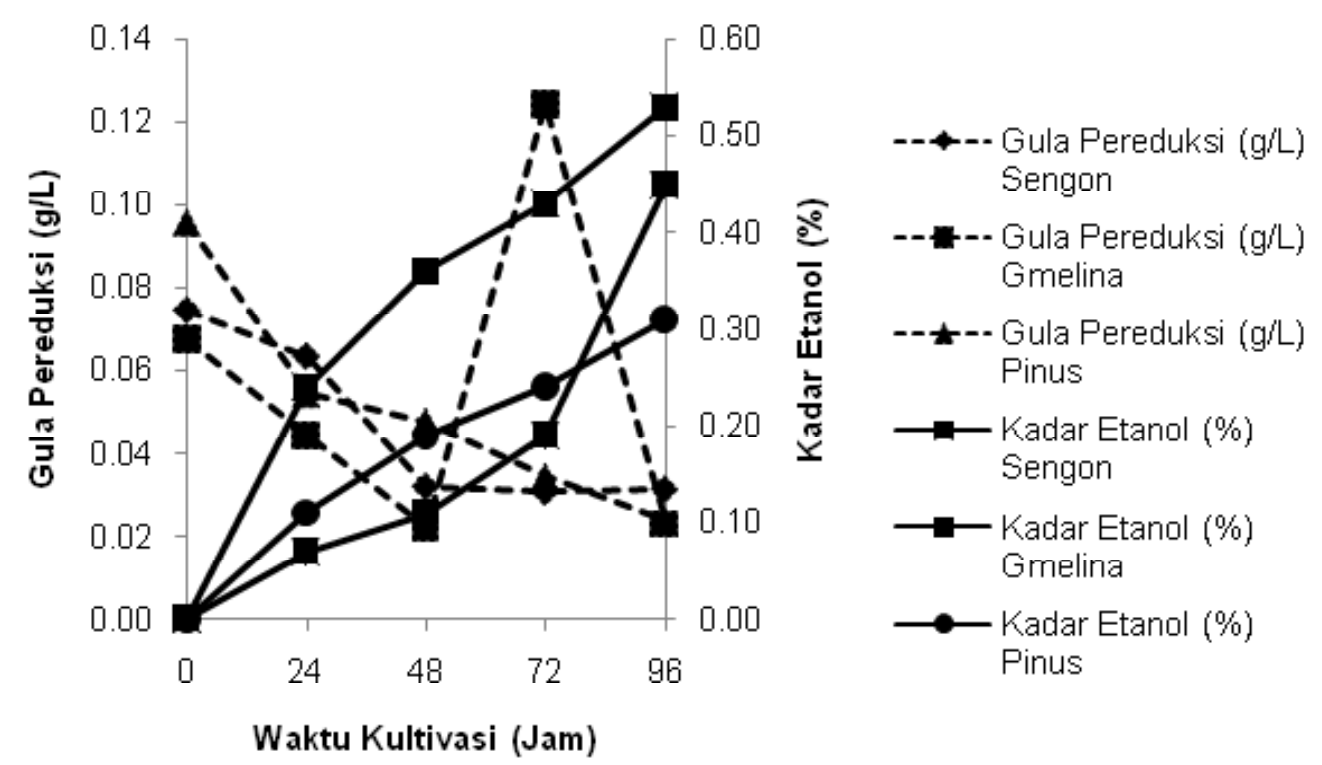

Gambar 2. Gula Pereduksi dan Kadar Etanol pada SSF dengan A. niger

pereduksi glukosa. Fase sakarifikasi berlangsung secara bertahap yang menghasilkan unit-unit glukosa. Efisiensi dan efektivitas proses hidrolisis ini dapat diukur melalui tingkat produksi gula pereduksi.

Penurunan jumlah gula pereduksi disebabkan oleh konversi gula pereduksi tersebut menjadi etanol oleh khamir S. cereviciae. Menurut Campbel (1983) proses fermentasi oleh $S$. cereviciae adalah proses pengubahan sebagian besar energi dari gula ke dalam bentuk etanol dengan efisiensi pengubahan energi sekitar $97 \%$. Mekanisme pembentukan etanol oleh khamir melalui jalur Embden-MeyerhofParnas Pathways (EMP) atau glikolisis. Hasil dari EMP adalah memecah glukosa menjadi 2 molekul piruvat. Setelah melalui tahap glikolisis, piruvat yang terbentuk kemudian diubah menjadi asetaldehida dan $\mathrm{CO}_{2}$ oleh enzim piruvat dekarboksilase, lalu diubah menjadi etanol oleh enzim alkohol dehidrogenase. Secara teoritis $100 \%$ glukosa dapat dikonversi menjadi sekitar $51 \%$ etanol dan $49 \%$ menjadi $\mathrm{CO}_{2}$. Menurut Boyles (1984), S. cereviciae merupakan khamir sangat baik dalam produksi etanol. Rendemen alkohol gula heksosa dari fermentasi dapat mencapai $90 \%$. Kelemahan khamir ini adalah hanya mampu memfermentasi gula-gula heksosa seperti glukosa dari hidrolisis selulosa dan sebagian selulosa menjadi etanol, sedangkan gula-gula pentosa seperti xilosa dan arabinosa tidak bisa difermentasi. Namun beberapa bakteri telah mulai direkayasa secara genetika seperti Escherina coli dan Zimomonas mobilis yang dilaporkan telah mampu memferntasi gula-gula pentosa menjadi etanol (Scheieder, 2005).

Penggunaan kultur murni $A$. niger dan khamir S. cereviciae pada proses SSF menghasilkan kadar etanol pada jam ke-96 berturut-turut pada kayu sengon, kayu gmelina, dan pinus menghasilkan kadar etanol berturut-turut sekitar 0,53; 0,45 dan $0,31 \%$. Hal ini menunjukkan penggunaan kultur murni $A$. niger sangat potensial dikembangkan dalam produksi bioetanol terutama dari bahan berlignoselulosa. Kayu dari jenis kayu daun lebar (gmelina dan sengon) menghasilkan kadar etanol yang lebih tinggi dibandingkan dengan jenis kayu daun jarum (pinus). Stemberg et al. (1999) menyatakan bahwa kayu daun jarum umumnya lebih sulit dihidrolisis menjadi gula dibandingkan dengan kayu daun lebar.

\section{Pertumbuhan Mikroba selama Proses SSF}

Gambar 3 dan 4 menunjukkan pertumbuhan A. niger dan khamir S. cereviciae selama kultvasi pada proses produksi bioetanol dengan metode SSF yang dihitung menggunakan masing-masing dengan metode total plate count (TPC) dan hitungan mikroskop (Haemacytometer). Kapang $A$. niger menunjukkan pertumbuhan yang cukup signifikan sampai jam ke-48 dan selanjutnya mengalami penurunan sampai jam ke-96 kecuali pada kayu gmelina yang menunjukkan pertumbuhan sampai jam ke-72 dan kemudian mengalami penurunan 


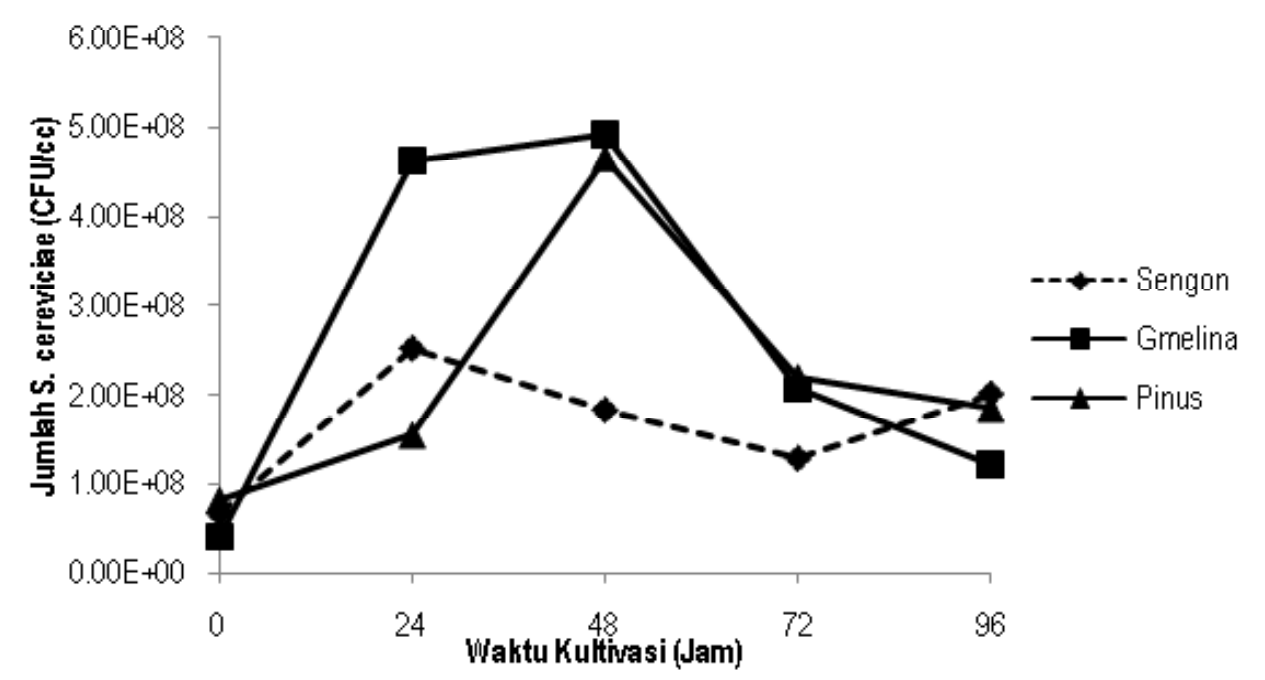

Gambar 3. Pertumbuhan Khamir S. cereviciae

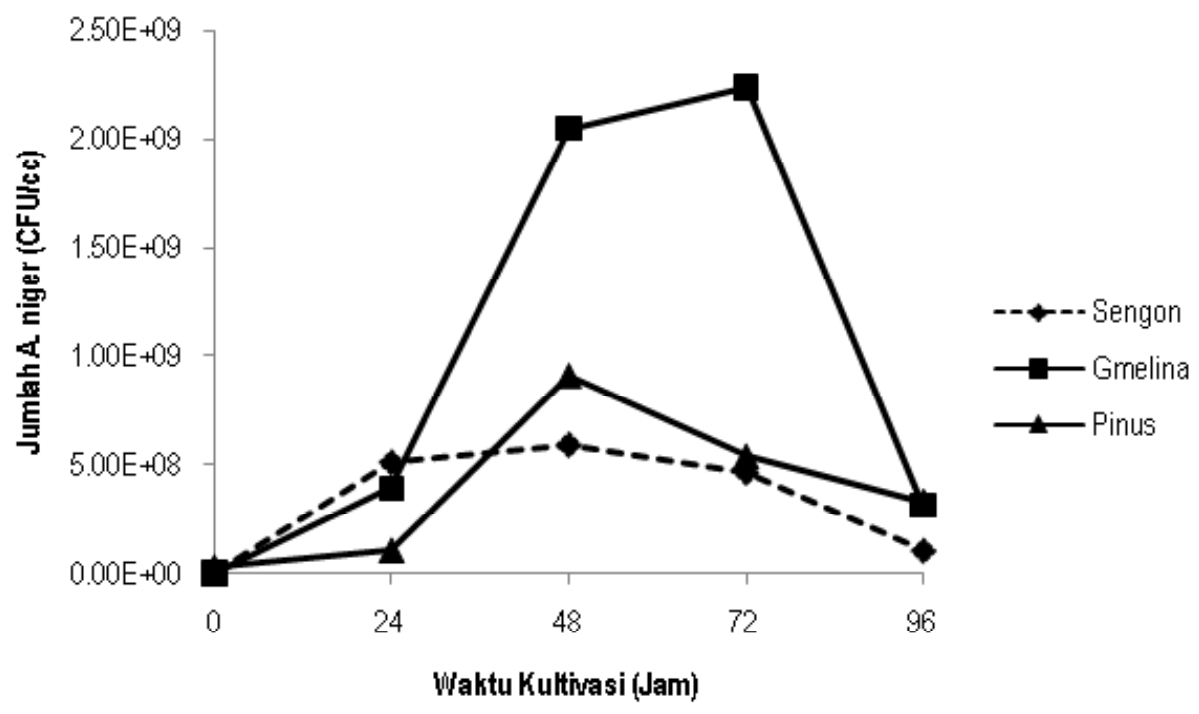

Gambar 4. Pertumbuhan A. niger

sampai jam ke-96. Peningkatan pertumbuhan kapang A. niger pada awal kultivasi disebabkan masih tingginya ketersedian subtrat pada awal kultivasi. Secara umum, pertumbuhan khamir $S$. cereviciae juga mengalami peningkatan sampai pada jam ke-24 kemudian cenderung fluktuatif dan akhirnya mengalami penurunan pada akhir kultivasi. Pertumbuhan ini sangat dipengaruhi oleh ketersediaan substrat gula yang diperoleh dari proses hidrolisis selulosa dan hemiselulosa oleh kapang A. niger. Selain itu, kandungan furaldehida, furfural asam organik dan komponen fenolik, serta 5-hidroksimetil-furfural bersifat menghambat pertumbuhan khamir S. cereviciae.

Menurut Stanbury \& Whaitaker (1993), setelah kultivasi kultur ke dalam media, terjadi suatu periode dimana kultur yang dimasukkan tersebut menyesuaikan diri dengan lingkungan yang baru, fase ini disebut dengan fase adaptasi. Setelah fase adaptasi, mikroorganisme kemudian memasuki fase log atau eksponensial. Pada fase ini, mikroorganisme membelah dengan cepat. Semua sel mempunyai kemampuan untuk berkembang biak dan tidak terdapat penghambatan pertumbuhan. Fase ini merupakan kondisi yang ideal bagi mikroorganisme yang digunakan (Judoamidjojo et al., 1989).

Fase selanjutnya adalah fase pertumbuhan lambat. Pada fase ini, pertumbuhan populasi mikroorganisme diperlambat karena beberapa faktor di antaranya zat-zat nutrisi dalam media yang sudah berkurang, serta adanya hasil metabolisme yang mungkin beracun sehingga dapat menghambat 
Tabel 3. Rendemen etanol pada beberapa jenis bahan baku

\begin{tabular}{ccccc}
\hline Jenis Bahan Baku & $\begin{array}{c}\text { Kadar Etanol Tertinggi } \\
\left(\% \vee v^{-1}\right)\end{array}$ & $\begin{array}{c}\text { Rendemen Etanol dari } \\
\text { Kayu }\left(\% \vee v^{-1}\right)\end{array}$ & $\begin{array}{c}\text { Produksi Etanol } \\
(\mathrm{L} \mathrm{ton}-1)\end{array}$ & $\begin{array}{c}\text { Produktivitas Etanol } \\
\left(\mathrm{L} \mathrm{ha}^{-1} \mathrm{thn}^{-1}\right)\end{array}$ \\
\hline Sengon & 0,53 & 3,61 & 109,49 & $1.204,36$ \\
Gmelina & 0,45 & 4,60 & 109,51 & $1.398,25$ \\
Pinus & 0,31 & 4,16 & 75,69 & 832,59 \\
\hline
\end{tabular}

pertumbuhan mikroorganisme (Fardiaz, 1988). Fase selanjutnya adalah fase stasioner, pada fase ini jumlah populasi sel cenderung tetap karena jumlah sel yang tumbuh hampir sama dengan jumlah sel yang mati. Pada fase stasioner ini, persediaan nutrient yang diberikan akan berkurang serta terjadi akumulasi zat-zat metabolik yang menghambat pertumbuhan (Stanbury \& Whitaker, 1993).

\section{Rendemen Etanol}

Rendemen adalah persentase perbandingan antara volume etanol yang diperoleh dengan volume bahan bahan baku yang digunakan (Stenberg et al., 2000). Rendemen etanol pada beberapa jenis bahan baku pada masing-masing proses hidrolisis ditunjukkan pada Tabel 3.

Berdasarkan Tabel 3 , rendemen etanol tertinggi terdapat pada kayu gmelina. Hal ini menunjukkan bahwa kayu tersebut mudah dihidrolisis dan difermentasi menjadi etanol. Dari segi produksi etanol, penggunaan kapang $A$. niger sebagai penghidrolis dan khamir $S$. cereviciae sebagai mikroba fermentasi dalam produksi bioetanol dengan metode SSF sangat menjanjikan meskipun produksi etanol yang dihasilkan masih lebih rendah dibandingkan dengan etanol dari Eucalytus grandis yaitu sekitar 225 I ton $^{-1}$ (Shleser, 1994), demikian pula dengan produktivitas etanol yang dihasilkan masih jauh di bawah ubi kayu, jagung dan talas yang berturut-turut memiliki produktivitas 7.200 , 4.620 dan $2.840 \mathrm{I} \mathrm{ha}^{-1}$ thn $^{-1}$ (Shintawatiy, 2006).

\section{KESIMPULAN}

Penggunaan kultur murni $A$. niger dan $S$. cereviciae dalam produksi bioetanol dari berbagai bahan baku lignoselulosa dengan menggunakan metode SSF menghasilkan kadar, rendemen, dan produktivitas etanol yang masih rendah. Rendemen dan produktivitas ini sangat dipengaruhi oleh bahan baku. Kayu daun lebar (gmelina dan sengon) menghasilkan kadar etanol dan produktivitas yang lebih tinggi dibandingkan kayu daun jarum (pinus). Kadar etanol pada beberapa jenis bahan baku lignoselulosa mengalami peningkatan dengan lamanya waktu kultivasi sedangkan gula total dan gula pereduksi cenderung mengalami penurunan, pertumbuhan S.cereviciae dan A. niger cenderung mengalami peningkatan pada awal kultivasi kemudian mengalami penurunan pada akhir kultivasi. Rendemen bioetanol dari bahan berlignoselulosa dengan menggunakan kultur murni A. niger dan S. cereviciae dalam produksi bioetanol dari berbagai bahan baku lignoselulosa dengan menggunakan metode SSF tertinggi terdapat pada kayu gmelina yaitu $4,60 \%$.

\section{DAFTAR PUSTAKA}

Boussaid, A., J. Robinson, Y. J. Cai, D. J.Gregg and J. N. Saddler. 1999. Fermentability of the HemicelluloseExploded Softwood (Douglas Fir). Journal of Biotechnology and Bioengineering 64 (3): 285-289.

Boyles, D. 1984. Bio Energy-Technology, Thermodynamic and Costs. West Sussex: Ellis Horwood

Campbell, I. M. 1983. Biomass, Catalysts and Liquid Fuel. Pensylvania: Technomic Publishing Co. Inc.

Dubois, M., K. A. Gilles, J. K. Hamilton, P. A. Rebers and F. Smith. 1956. Colorimetric Method for Determination of Sugar and Related Substances. J. Anal Chem. 28 (3): 350-356.

Fardiaz, S. 1988. Fisiologi Fermentasi. Bogor: Pusat Antar Universitas, Institut Pertanian Bogor.

Ingram, L. O., P. F. Gomez, X. Lai, M. Moniruzzaman, B. E. Wood, L. P. Yamano and S. W. York. 1999. Metabolic Engineering of Bacteria for Ethanol Production. Journal of Biotechnology and Bioengineering 58 (2): 204-214.

Jeffries, T. W. 1994. Biochemistry of Microbial Degradation. Ratlefge C, editor. Netherland: Kluwer Academic Publishers.

Judoamidjojo, R. M., E. G. Said and L. Hartoto. 1989. Biokonversi. Bogor: Pusat Antar Universitas Bioteknologi.

Martinez, A., M. E. Rodriguez, S. W. York, J. F. Preston and L. O. Ingram. 2000. Effects of $\mathrm{Ca}(\mathrm{OH})_{2}$ Treatments (Overliming) on the Composition and Toxicity of Bagasse Hemicellulose Hydrolysates. Journal of Biotechnology and Bioengineering 69 (5): 526-536. 
Miller, G.L. 1959. Use of Dinitrosalicylic Acid Reagent for Determination of Reducing Sugar. J. Anal Chem 31 (3) 300-310.

Neureiter, M, H. Danner, C. Thomasser, B. Saidi and R. Braun. 2002. Dilute acid Hydrolysis of Sugar Cane Bagasse at Varying Conditions. Journal of Application Biochemical Biotechnology 98-100: 49-58.

Samejima, M. 2008. Scenario of Technical Innovation for Production of Ethanol as Automobile Fuel from Cellulosic Biomass in Japan. Proceedings International Symposium on Wood Scienceand Technology. Harbin, China, 2729 Sep 2008. Harbin: Iternational Association of Wood Products Societies.

Sceieder, D. 2005. Bioethanol Existing Pathways. First European Summer School on Reneable Motor Fuels. Birkenfeld, Germany, 29-31 August 2005.

Selvakumar, P., L. Ashkumary, A. Helen and P. Ashok. 1996. Purification and Characteristic of Glucoamylase Produced by Aspergillus niger in Solid State Fermentation. Appl. Microbiol 23;403-406.

Smith, M. T., P. Sommer and B. K. Ahring. 2003. Purification of Bioetanol Effluent in an UASB Reactor System With Simultaneous Biogas Formation. Journal of Biotechnology and Bioengineering 84 (1): 8-12.

Spagnuolo, M., C. Crecchio, M. D. R. Pizzigallo and P. Ruggiero. 1999. Fractionation of Sugar Beet Pulp into Pectin Cellulose, and Arabinases Combined with Ultrafiltration. Journal of Biotechnology and Bioengineering 64 (6): 685691.
Stanbury, P. F. and A. Whitaker. 1993. Principle of Fermentation Technology. New York: Pergamon Press.

Stenberg, K., C. Tengborg, M. Gable and G. Zacchi. 1998. Optimisation of Steam Pretreatment of SO2-Impregnated Mixed Softwoods for Ethanol Production. J Chem Technol Biotechnol. 71:299-308.

Stenber, K., M. Gable and G. Zacchi. 1999. The Influence of Lactic Acid Formation on Simultaneous Saccharification and Fermentation (SSF) of Softwood to Ethanol. J Enzyme Microb Biotechnol. 70:697-708.

Stenberg, K., M. Bollok, K. Reczey, M. Galbe and G. Zacchi. 2000. Effect of Substrate and Cellulase Concentration on Simultaneous Saccharification and Fermentation of SteamPretreated Softwood for Ethanol Production. Journal of Biotechnology and Bioengineering 68 (2): 204-210.

Syafii, W. 2001. The Effect of Lignin Composition on Delignification Rate of Some Tropical Hardwoods. Indonesian Journal of Tropical Agriculture. 10 (1) :9-13.

Syafii, W., D. S. Nawawi and D. Nurhayati. 2009. Rasio SiringilGuaiasil Struktur Lignin Beberapa Jenis Kayu Daun Lebar dan Pengaruhnya Terhadap Laju Delignifikasi. Simposium Nasional Forum Teknologi Hasil Hutan. "Peningkatan Peran FTHH dalam Penelitian dan Pengembangan IPTEK untuk Menunjuang Revitalisasi Industri Hasil Hutan Indonesia”. Bogor,30-31 Oktober 2009. 